\title{
Comparative Cost Analysis Between Hydraform Interlocking Brick and Sandcrete Block as Walling Materials for Low-Cost Housing Development in Nigeria
}

\author{
Aligamhe, Victor Imohnikhe ${ }^{1} \quad$ Alao Mohammed Kaseem ${ }^{2} \quad$ Dania, Sunday Festus ${ }^{2}$ \\ 1.Quantity Surveying Department, Auchi Polytechnic, Auchi \\ 2.Building Technology Department, Auchi Polytechnic, Auchi
}

\begin{abstract}
This study analyzed the cost of production and construction of $225 \mathrm{~mm}$ hollow sandcrete blocks and hydraform interlocking bricks and walls to compare the findings of the results. The study was conducted in Auchi, Estako West Local Government Area of Edo State, Nigeria. The study compared the construction of two models of $225 \mathrm{~mm}$ hollow sandcrete blocks and hydraform interlocking bricks, materials employed for wall construction for the study are; clay, cement, sand, water and mould. The result of the study indicates that unit cost of $225 \mathrm{~mm}$ hollow sandcrete block and hydraform interlocking bricks are $\$ 168.57$ and $\$ 57.85$ respectively. While the cost per square metre of $225 \mathrm{~mm}$ hollow sandcrete block wall and hydraform interlocking brick wall are $\$ 3,199.40$ and $\$ 3,079.52$ respectively. The study also revealed that it is more costly to apply finishes to sandcrete block wall when compared with hydraform interlocking brick wall. Sandcrete block wall requires rendering or plastering to both faces of the walls, while hyraform interlocking wall requires rendering of not more than $300 \mathrm{~mm}$ girth to vertical external corners of the brick wall. The study, therefore, recommends the use of hydraform interlocking bricks for low-cost housing to reduce the housing deficit in Nigeria.
\end{abstract}

Keywords: Sandcrete block; hydraform interlocking brick; walling; cost analysis; Auchi;

DOI: $10.7176 / \mathrm{JNSR} / 11-22-07$

Publication date: November $30^{\text {th }} 2020$

\subsection{Introduction}

Housing is central to virtually all of the activities of humans. It is required to provide safety, comfort, convenience, learning, and satisfaction to its users [1]. Essentially, housing has become a key social indicator in the assessment of the living standards of humans nationwide [2]. However, despite the importance of housing, the world is witnessing a chronic undersupply of it. Along this line, studies have affirmed that close to a billion persons in the world is displaced concerning housing [3][4].

Similarly, the continent of Africa has equally been reported to be witnessing a severe shortage of housing. The [5]report has affirmed that around $61.7 \%$ of the population of Africans are displaced concerning housing. In Nigeria, a recent report from [6] has affirmed that the country's housing deficit figures currently hovers around 1720 million. Furthermore, researches have affirmed that from among those who are displaced concerning housing globally, the lower-income citizens are the prime sufferers $[7,8,9,10,11]$. Similar studies have equally confirmed that low-income earners in Nigeria who are over $90 \%$ of the population of the country are homelessness because they reside in squatter settlements and shanty dwellings [12, 13, 14, 15, 16, 17].

However, the increasing cost of building materials has been advanced as one of the reasons for the worsening state of low-income housing in developing nations like Nigeria[18, 19, 20] Building materials have been reported to be the highest cost contributor of the entire cost of a building in most emerging nations. In Nigeria for example, it has been established that building materials alone account for more than half of the total cost housing development [21]. Similar studies have equally affirmed that building materials take up to 70-75 per cent of the total cost of a standard residential development in Nigeria [22, 20]. Of this percentage, walling materials reportedly accounts for more than $15 \%$ of the total building cost [23].

Walling materials are an important component of a building as a result of the enormous role it plays concerning thermal comfort through the reduction of external heat gained during the day [24]. Sandcrete blocks have been predominantly used as walling materials for housing development in Nigeria. However, as a result of the worsening state of housing with particular reference to low-income earners in Nigeria occasioned by the increasing cost of building materials, cost-saving strategies in low-cost housing development is expedient.

This study, therefore, aims to compare the cost of sandcrete blocks and hydraform interlocking bricks as walling materials for low-cost housing development in Nigeria. Findings from this study would be of immense value to the government, funding agencies, private developers and the general public in the area of mass housing development for low-income earners in Nigeria and other developing nations. The study's findings shall equally re-direct academics and research interests. To achieve the study's aim, this paper is therefore structured as follows: Introduction, methodology, cost analysis, conclusion and recommendations. 


\subsection{Methodology}

The study compared the construction of two models of $225 \mathrm{~mm}$ hollow sandcrete blocks and hydraform interlocking bricks. Materials used for producing sandcrete hollow blocks and hydraform interlocking bricks were purchased from Auchi and Agbedearea of Estako West Local Government Area of Edo State, Nigeria

\subsection{Materials}

Cement: The cement used was Elephant cement an Ordinary Portland Cement (OPC) purchased from a cement depot in Auchi, and it conformed to BS 12 (1978) as cited in [25].

Sharp Sand: Sand purchased from Chinese Quarry at Uloeke in Estako West LGA, Edo State, Nigeria. The material confirmed [26].

Water: water used for the work was sourced from the deep borehole and fit for drinking, free from contaminants either dissolved or in suspension as specified by [27].

Lateritic Clay Soil: The lateritic clay soil used in the study was obtained from a borrow pit in Agbede, Nigeria between a depth of $1.5 \mathrm{~m}$ to $2.0 \mathrm{~m}$ using the method of disturbed sampling.

Production of Sandcrete Blocks: Mixes of Cement/Sand ratio 1:14 (1 head pan of cement to 14 head pans of sand) produced 35 hollow sandcrete blocks of $225 \mathrm{~mm}$ x $225 \mathrm{~mm}$ x $450 \mathrm{~mm}$. And curing of the blocks took place under laboratory conditions for 7, 21, and 28 days. Compaction test was carried out in accordance with [28].

Production of hydraform interlocking bricks: 1:19 (that is, one part of ordinary Portland cement: nineteen parts of clay soil) and Cement/Clay ratio 1:12 (1 head pan of cement to 19 head pans of clay soil) 59 bricks were moulded for each mix, the cement stabilized clay bricks of size $230 \mathrm{~mm}$ x $230 \mathrm{~mm}$ x $115 \mathrm{~mm}$ were produced and cured under laboratory conditions for 7, 21, and 28 days curing periods. Compaction test was carried out in accordance with [28].

Cost Analysis: Cost analysis at the time of this study was based on per square metre of both clay bricks and sandcrete blocks respectively and results are presented in findings and discussion below.

\subsection{Cost Analyses of $225 \mathrm{~mm}$ Sandcrete Block Wall Construction and Hydra Form Interlocking Brick Wall Construction.}

\subsection{Built-Up Rates for Block Works}

$225 \mathrm{~mm}$ sandcrete hollow block wall laid with cement and sand mortar (1:4) in stretcher bond.... $\mathrm{m}^{2}$

\section{i Block Production}

Mix Ratio $=1: 14$

This translates to one bag of ordinary Portland cement to twenty-eight head pans of sand, since there are two head pans in a bag of cement. The cost of one bag of ordinary Portland cement is $\$ 2,500$ as at the time of carrying out the research.

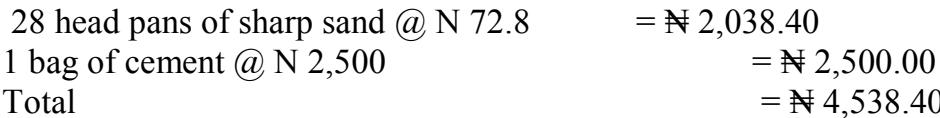

For 225mm block, N 4,538.4 produced 35 blocks.

Cost of materials for producing 1 unit of $225 \mathrm{~mm}$ sandcrete block $\quad=\$ 129.67$

Assume $10 \%$ for labour $=12.97$

Assume also $20 \%$ for plant and others $=25.93$

Total cost incurred in producing one unit of $225 \mathrm{~mm}$ sandcrete hollow block $\quad=168.57$ ii $\quad$ Mortar (for 1 block)

Mix ratio = $=1: 4-25 \mathrm{~mm}$ thick

Total ratio $\quad=1+4=5$

Bedding $\quad=0.45 \times 0.225 \times 0.025=0.0025 \mathrm{~m}^{3}$

Jointing $\quad=0.225 \times 0.225 \times 0.025=0.0013 \mathrm{~m}^{3}$

Total volume/block $\quad=0.0038 \times 1=0.0038 \mathrm{~m}^{3}$

Cement

Part by cement

$$
=\frac{1 \times 0.0038 \mathrm{~m}^{3}}{5}
$$

Add: waste say $5 \%$

$$
\begin{array}{r}
=0.000760 \mathrm{~m}^{3} \\
0.000038 \mathrm{~m}^{3} \\
\hline
\end{array}
$$

Since $1 \mathrm{~m}^{3}=28.82 \mathrm{bags}$ of $50 \mathrm{~kg}$ cement

Nos. of bags $=0.000798 \times 28.82=0.022998$ bags

Cost of cement incurred in laying one unit of $225 \mathrm{~mm}$ sandcrete hollow block

$$
=\mathrm{N} 2,500.00 / \mathrm{bag} \times 0.022998 \mathrm{bag} / \mathrm{block} \quad=\quad 57.50
$$


$\underline{\text { Sand }}$

4 part by sand $=\frac{4 \times 0.0038 \mathrm{~m}^{3}}{5}$

$$
\begin{gathered}
=0.003040 \mathrm{~m}^{3} \\
\frac{0.000152 \mathrm{~m}^{3}}{0.003192 \mathrm{~m}^{3}}
\end{gathered}
$$

Note: using a tipper capacity of $3.82 \mathrm{~m}^{3}$

No. of trips $=\underline{0.003192 \mathrm{~m}^{3}}$

$$
3.82 \mathrm{~m}^{3} \quad=\underline{0.000836 \text { trip }}
$$

Cost of Sand incurred in laying one unit of $225 \mathrm{~mm}$ sandcrete hollow block

$$
=\quad 22,500.00 / 3.82 \text { Trip } \times 0.000836 \text { trip } / \text { block }=18.80
$$

Cost of Cement in mortar

$$
\begin{array}{r}
=57.50 \\
=18.80 \\
\quad 76.30
\end{array}
$$

Assume 5\% for Water in mortar $=3.82$

$$
\text { 80.12 }
$$

Total cost of Mortar in laying one unit of $225 \mathrm{~mm}$ sandcrete hollow block

iii $\quad$ Labour( for 1 block)

Laying: skilled and unskilled

0.10hrs@ $@ 437.50$ (skilled)

$¥ 43.75$

0.10hrs@275.00 (unskilled)

$\frac{\$ 27.50}{\$ 71.25}$

The total cost of Labour in laying one unit of $225 \mathrm{~mm}$ sandcrete hollow block $=\mathbf{7 1 . 2 5}$

Production of block Summary

Mortar of laying block $=\mathrm{N} 168.57$

Labour cost of laying block

The total cost incurred in producing and laying one unit of $225 \mathrm{~mm}$ block

iv $\quad$ Cost Per Square Metre Of Sandcrete Blocks

Elevation area of sandcrete block $\quad=0.450 \mathrm{~m} \times 0.225 \mathrm{~m} \quad=0.1013 \mathrm{~m} 2$

Number of sandcrete blocks in one square metre $\quad=1.00 \div 0.1013=9.87$

Approximately 10 Blocks

Cost of $225 \mathrm{~mm}$ sandcrete hollow blocks per square metre $=10 \times 319.94$

\subsection{Built-Up Rates For Hydraform Interlocking Bricks Works}

$230 \mathrm{~mm} \times 115 \mathrm{~mm}$ interlocking brick $\mathrm{m}^{2}$

i Unit Cost of Laterite Interlocking Brick

Mix Ratio $=1: 19$ (that is, one part of ordinary Portland cement: nineteen parts of laterite)

A four (4) litre Plastic container was used as the gauge in measuring the composition of laterite interlocking block. There is four number of a plastic container (each 4litre capacity) in one head pan. Since there are two head pans in one bag of cement, this means that eight number of plastic containers (each 4litre capacity) are contained in one bag of cement.

Cost of buying 1 cement bag of laterite $=$ N500

The cost of one bag of ordinary Portland cement is 2500 as at the time of carrying out the research.

Cost of one, 4litre plastic container of Laterite

$$
\begin{aligned}
& =500 \div 8 \quad=\quad 62.50 \\
& =2,500 \div 8 \\
& =\text { ₹ } 1,178.95 \\
& =\mathrm{N} 312.50 \\
& =\$ 200.00 \\
& =1,690.95
\end{aligned}
$$$$
\text { Cost of one, 4litre plastic container of Cement }
$$$$
19 \text { parts of laterite@ N 62.05/part }
$$$$
1 \text { part of cement@N 312.50/part }
$$$$
\text { Polythene sheet for curing }
$$

Cost of materials used

N 1,690.95 produced 38 blocks

Cost of producing one unit of laterite interlocking block $=44.50$

Assume $10 \%$ for labour

$=4.45$

Assume also $20 \%$ for plant and others

$=\mathrm{N} .90$

Total cost incurred in producing one unit of laterite interlocking block $=\overline{57.85}$ 
ii $\quad$ Labour (For 1 Block)

Brick laying: skilled

$0.053 \mathrm{hrs} @ \$ 437.50$ (work study) = $¥ 23.19$

The total cost of Labour in laying one unit of hydra form interlocking brick $=\mathbb{2} 23.19$

Production of Hydra form interlocking brick

Summary

Labour cost of laying block

The total cost incurred in producing and laying one unit of $225 \mathrm{~mm}$ block

\section{$=\mathbf{N 5 7 . 8 5}$

iii Cost Per Square Metre Of Sandcrete Blocks

Elevation area of sandcrete block $\quad=0.230 \mathrm{~m} \mathrm{x} 0.115 \mathrm{~m} \quad=0.02645 \mathrm{~m} 2$

Number of hydra form interlocking brick in one square metre $=1.00 \div 0.02645 \quad=37.81$

Approximately 38 Blocks

Cost of $225 \mathrm{~mm}$ X $115 \mathrm{~mm}$ hydra form interlocking brick per square metre $=38 \times 81.04=\mathbf{=} \mathbf{3 , 0 7 9 . 5 2}$

3.3 Cost Comparison of Sandcrete Block Wall and Hydra form Interlocking Bricks

\begin{tabular}{|c|c|c|c|c|}
\hline Items & Description & Cost Activities & $\begin{array}{l}\text { Sandcrete Block } \\
\text { Wall }\end{array}$ & $\begin{array}{lr}\text { Hydra } & \text { form } \\
\text { interlocking } & \text { Brick } \\
\text { Wall } & \\
\end{array}$ \\
\hline A & Preliminary & Setting out & $\bullet$ & $\bullet$ \\
\hline B & Builders' work & $\begin{array}{l}\text { Block/ Interlocking brick } \\
\text { Mortar (Bedding and jointing) } \\
\text { Labour }\end{array}$ & $\begin{array}{l}\bullet \\
\bullet \\
\bullet\end{array}$ & • \\
\hline $\mathrm{C}$ & Wall Finishes & $\begin{array}{l}\text { Rendering/plastering to the wall } \\
\text { (Externally and internally) } \\
\text { Rendering to corners of the wall } \\
\text { (Externally) } \\
\text { Painting to wall }\end{array}$ & • & $\bullet$ \\
\hline
\end{tabular}

Legend:

- Applicable step

$\circ$ Eliminated / non-value adding step

\subsection{Cost Analyses}

The above results show the various cost for the production of $225 \mathrm{~mm}$ hollow sandcrete blocks alongside the cost of producing hydra form interlocking cement stabilized bricks. At the time of the research, the cost for the production of a unit of the block was 168.57 , while the cost of producing a unit of hydra from interlocking cement stabilized bricks, on the other hand, was $\$ 57.85$. In constructing hydra form interlocking bricks wall, apart from the base mortar that requires a thin layer of mortar to link the first course to the floor, no mortar is required for the subsequent courses of the hydra from interlocking walling system. The absence of mortar bedding and jointing in the hydra form interlocking brick walling process led to a significant reduction in the quantity of mortar used compared to the case of the sandcrete block. The total cost for constructing one metre square of sandcrete block wall was 3 3,199.40 inclusive of material and labour. While that of the hydra form of the interlocking brick wall was $¥ 3,079.52$.

The results revealed that it is more costly to apply finishes to sandcrete block wall when compared with hydra form of an interlocking brick wall.Sandcrete block wall requires rendering or plastering which include the application of a smooth coat of material to walls to provide a joint-less, hygienic, easily decorated smooth finish to walls as well as to covers up the unevenness in the block wall. While on the other hand, hydra form interlocking bricks wall do not require rendering or plastering thereby resulting in significant cost savings on plastering. Painting can be applied to both sandcrete block wall and brick wall; however, hydra form interlocking blocks are also aesthetically pleasing and may not require painting. It is therefore recommended for affordable low-cost mass housing development.

\subsection{Conclusion}

The following conclusions can be drawn from the results of cost analyses of hollow sandcrete block and hydra form interlocking brick wall as experimented:

i. Hydra form interlocking brick wall construction significantly reduces non-value-adding steps when 
compared with the conventional sandcrete block wall construction.

ii. Interlocking brick wall construction eliminates the cycle time of block bonding thus increasing the speed of wall construction for interlocking blocks.

iii. Hydra form interlocking blocks are affordable in terms of cost. There is also a significant reduction in the material required for the interlocking block wall construction process due to the absence of mortar jointing.

iv. Reduction in the labour and material requirements in the hydra form interlocking block wall construction makes the cost associated with the process of building walls using the interlocking blocks less expensive.

v. The cost of applying basic wall finishing to hydra form interlocking brick wall construction is significantly cheaper when compared with sandcrete block wall construction. Hydra form interlocking brick wall does not require plastering to both faces of the wall, thereby resulting in cost savings for plastering to the wall.

\subsection{Recommendations}

The study, therefore, recommends the following:

i. The use of hydraform interlocking bricks for the production of low-cost to reduce the housing deficits in Nigeria.

ii. The government should provide affordable mass housing schemes using hydraform interlocking bricks for her low-income earners through mortgage arrangement.

iii. Stakeholders in the construction industry should commercialize the technology for the production of hydraform interlocking bricks walling system in Nigeria.

Future researches are encouraged in the areas of:

i. Comparative analysis of sandcrete block wall and hydra form interlocking bricks concerning functionality.

ii. Performance of the two (2) walling materials in different atmospheric conditions.

\section{Acknowledgements:}

The authors sincerely appreciate Tertiary Education Trust Fund (TETFUND) for the funding received through its Institutional Based Research Intervention through Auchi Polytechnic, Auchi. The authors' gratitude equally goes the polytechnic management for nominating this research to be funded through TetFund. Special thanks equally go to the editor and anonymous reviewers for their comments and suggestions.

Conflicts of Interest: The authors declare no conflict of interest

\section{References}

[1] I. Ezennia and S. Hoskara, "Exploring the Severity of Factors Influencing Sustainable Affordable Housing choice: Evidence from Abuja, Nigeria," Sustainability, vol. 11, pp. 1-25, 2019.

[2] M. Adabre, A. Chan, A. Darko, R. Osei-Kyei, R. Abidoye and T. Adjei-Kumi, "Critical Barriers to Sustainability Attainment in Affordable Housing: International Construction Professionals' Perspective," Journal of Cleaner Production, pp. 1-18, 2020.

[3] S. Enoghase, A. Airahuobhor, P. Oladunjoye, E. Okwuke, A. Orukpe, B. Ogunwusi and S. Bakare, "Nigeria's 17 Million Housing Deficit Challenges Buhari Daily Independent," 2015.

[4] J. Woetzel, S. Ram, J. Mischke, N. Garemo and S. Sankhe, A blueprint for addressing the global affordable housing Challenge, McKinsey Global Institute, 2014.

[5] UN-Habitat, "Planning and Design for Sustainable Urban Mobility: Global Report on Human Settlements 2013," Routledge, Abingdon, 2013a.

[6] Centre for Affordable Housing Finance, Africa, "Housing Finance in Nigeria," http://housingfinanceafrica.org/countries/nigeria/, 2018.

[7] M. Adabre and A. Chan, "Critical Success Factors (CSFs) for Sustainable Affordable Housing," Building and Environment, vol. 156, pp. 203-214, 2019.

[8] P. Igwe, C. Okeke, K. Onwurah, D. Nwafor and C. Umeh, "A Review of Housing Problems," International Journal of Environment, Agriculture and Biotechnology, vol. 2, no. 6, pp. 3092-3099, 2017.

[9] A. Rigon, "Collective or individual tiles? Conflict over tenure regularisation in a Kenya Informal Settlement," Urban Studies, vol. 53, no. 1, pp. 2758-2778, 2016.

[10] J. Sachs, "The Age of Sustainable Development: Sustainable Development as an Analytical and Normative Concept," The European Policy Review, 2015.

[11] A. Gilbert, "'Free housing for the poor: an alternative way to address poverty"," Habitat International, vol. 41, pp. 253-261, 2014.

[12] T. Oni-Jimoh and C. Liyanage, "Urbanization and Meeting the Need for Affordable Housing in Nigeria," IntechOpen, pp. 73-91, 2018. 
[13] O. Bons, A. Onochie and N. Nzewi, "Where is Home for the Abuja, Nigeria Urban Poor?," Intl. J. Trend. Sci. Res. Dev., vol. 3, pp. 45-56, 2019.

[14] M. Ismail, I. Ezra, M. Abdulkadir, A. Muhammed and T. Hadiza, "Urban Growth and Housing Problems in Karu.," Global Journal of Research and Review, vol. 2, no. 1, pp. 1-13, 2015.

[15] B. Okafor, "The Residential Housing Problem in Anambra State (A Case Study of Onitsha Metropolis)," International Journal of Civil Engineering, Construction and Estate Management, vol. 4, no. 2, pp. 1-18, 2016.

[16] A. Olotuah and A. Taiwo, "Housing Strategies and Quality of Housing in Nigeria: what lessons from Wales?," Developing Country Studies, vol. 5, no. 16, pp. 1-7, 2015.

[17] Federal Government of Nigeria, "National Housing Policy," Federal Ministry of Lands, Housing and Urban Development, Abuja, 2012.

[18] O. Adegun, A. Joseph and A. Adebusuyi, "Housing Affordability among Low-Income Earners in Akure, Nigeria," in Material Science and Engineering, 2019.

[19] M. Mukhtar and R. Amirudin, "Housing Delivery Problems in Developing Countries: a case study of Nigeria," Journal of Facilities Management, vol. 14, no. 4, pp. 315-329, 2016.

[20] I. B. Ugochukwu and I. Chioma, "Local Building Materials: an affordable strategy for housing the urban poor in Nigeria.," Procedia Engineering, vol. 118, pp. 42-49, 2015.

[21] FGN, "National Housing Policy," Federal Government Press, Lagos, 1991.

[22] C. Udechukwu, "Obstacles to individual homeownership in Nigeria," Journal of Housing Market s and Analysis, vol. 1, no. 2, pp. 182-194, 2008.

[23] C. Udawattha and R. Halwatura, "Life cycle cost of different Walling materials used for affordable housing in tropics," Case Studies in Construction Materials, vol. 7, pp. 15-29, 2017.

[24] C. Udawattha and R. Halwatura, "The embodied energy and life cycle costing: A case study on basic dwellings in Sri Lanka," in National Green Conference, 2016.

[25] M. D. Yahaya, "Quantitative Analysis of the Chemical Compositions of Selected Cement Brands in Nigeria," in Proceedings of Biennial Engineering Conference, held in FUT Minna, Yahaya, M. D. (2008). Quantitative Analysis of the Chemical Compositions of Selected Cement Brands in Nigeria. ProceNiger State, Nigeria, 2008.

[26] BS 882, "Aggregates from Natural Sources for Concrete," British Standards Institution, British Standard House, 2 Park Street, London, WIY 4AA, 1983.

[27] BS 3148, "Tests for Water for Making Concrete," British Standards Institution, British Standard House, 2 Park Street, London, WIY 4AA, 1980.

[28] BS 1377, "Methods of Testing Soils for Civil Engineering Purposes," British Standard Institution, British Standard House, 2 Park Street, London, WIY 4AA, 1990. 